\title{
Synthesis, Characterization, and Hydrogen Gas Sensing of $\mathrm{ZnO} / \mathrm{g}-\mathrm{C}_{3} \mathrm{~N}_{4}$ Nanocomposite ${ }^{\dagger}$
}

\author{
Arif Ibrahim ${ }^{1,2,3, * \mathbb{D}}$, Uzma Bano Memon ${ }^{1,2,3}$, Siddartha Prakash Duttagupta ${ }^{1}$, Raman R. K. Singh ${ }^{3}$ \\ and Arindam Sarkar 4
}

check for

updates

Citation: Ibrahim, A.; Memon, U.B.; Duttagupta, S.P.; Singh, R.R.K.;

Sarkar, A. Synthesis, Characterization, and Hydrogen Gas Sensing of $\mathrm{ZnO} / \mathrm{g}-\mathrm{C}_{3} \mathrm{~N}_{4}$ Nanocomposite. Eng. Proc. 2021, 10, 3. https://doi.org/ $10.3390 /$ ecsa-8-11337

Academic Editor: Stefano Mariani

Published: 8 December 2021

Publisher's Note: MDPI stays neutral with regard to jurisdictional claims in published maps and institutional affiliations.

Copyright: (c) 2021 by the authors. Licensee MDPI, Basel, Switzerland. This article is an open access article distributed under the terms and conditions of the Creative Commons Attribution (CC BY) license (https:// creativecommons.org/licenses/by/ $4.0 /)$.
1 IITB-Monash Research Academy, Mumbai 400076, India; uzb.mem@gmail.com (U.B.M.); sdgupta@ee.iitb.ac.in (S.P.D.)

2 Department of Electrical Engineering, Indian Institute of Technology Bombay, Bombay 400076, India

3 Department of Chemical Engineering and Department of Mechanical \& Aerospace Engineering, Monash University, Melbourne, VIC 3800, Australia; raman.singh@monash.edu

4 Department of Chemical Engineering, Indian Institute of Technology Bombay, Bombay 400076, India; asarkar@che.iitb.ac.in

* Correspondence: arifibrahim.iitb@gmail.com

+ Presented at the 8th International Electronic Conference on Sensors and Applications, 1-15 November 2021; Available online: https:/ / ecsa-8.sciforum.net.

\begin{abstract}
In this paper, the preparation of the $\mathrm{ZnO} / \mathrm{g}-\mathrm{C}_{3} \mathrm{~N}_{4}$ nanocomposite is discussed. The synthesis of nanocomposite is performed by the direct pyrolysis of the precursor (zinc acetate hexahydrate). The material synthesis is validated by different characterization tools, such as X-ray Diffraction (XRD), Scanning electron microscopy (SEM), Transmission electron microscopy (TEM). The SEM and TEM analysis revealed the formation of nanorods on $\mathrm{g}-\mathrm{C}_{3} \mathrm{~N}_{4}$ support. The gas sensing property of the $\mathrm{ZnO} / \mathrm{g}-\mathrm{C}_{3} \mathrm{~N}_{4}$ was studied for various concentrations of hydrogen gas. Response and recovery times were recorded by the sensor.
\end{abstract}

Keywords: hydrogen gas sensor; graphitic carbon nitride; $\mathrm{ZnO} / \mathrm{g}-\mathrm{C}_{3} \mathrm{~N}_{4}$

\section{Introduction}

Hydrogen is increasingly important as a clean energy source due to its relatively easy availability and eco-friendliness. Moreover, hydrogen is efficient and renewable, and its common by-product is water [1]. For these features, hydrogen is the most promising green energy source for automotive and other industries and technologies, such as fuel cells, defence, petroleum, etc. Hydrogen gas is very explosive and fatal above its lower explosion limit (1-4\%). The $\mathrm{g}-\mathrm{C}_{3} \mathrm{~N}_{4}$ is a $2 \mathrm{D}$ conjugated polymer semiconductor [2]. It is an n-type semiconductor, which has nitrogen in abundance. It is a thermally stable, nonpoisonous, metal-free, and low-cost material [3]. The g- $\mathrm{C}_{3} \mathrm{~N}_{4}$ has suitable band structures that are highly thermal; have chemical stabilities; have excellent electronic properties; and are abundant in nature [2,3]. The $\mathrm{g}-\mathrm{C}_{3} \mathrm{~N}_{4}$ has been applied in photosynthesis, energy conversion and storage, carbon dioxide storage and reduction, solar cells, sensing, and imaging [4]. The $\mathrm{g}-\mathrm{C}_{3} \mathrm{~N}_{4}$ comprises excellent properties as a gas sensing material. It possesses an indirect bandgap of 2.7-2.8 eV, consisting of carbon $(\mathrm{C})$ and nitrogen $(\mathrm{N})$ atoms that are organized in the graphite-like layered structure; each layer has tri-s-triazine, which is connected to the amino group [5].

\section{Preparation of $\mathrm{ZnO} / \mathrm{g}-\mathrm{C}_{3} \mathrm{~N}_{4}$ Nanorods}

To synthesize the $\mathrm{ZnO} / \mathrm{g}-\mathrm{C}_{3} \mathrm{~N}_{4}$ nanocomposite, melamine was taken as a precursor material for $\mathrm{g}-\mathrm{C}_{3} \mathrm{~N}_{4}$ and zinc acetate dehydrates for $\mathrm{ZnO}$. Melamine and zinc acetate dehydrates were purchased from Merck India Pvt. Ltd., Mumbai, India. Pure DI water was generated using Milli-Q Advantage A10 (Merck Millipore, Burlington, VT, USA). 
All the materials taken for the synthesis were used as-received (i.e., without any further purification). For the synthesis, a very simple and cost-effective pyrolysis process was adopted. The $\mathrm{ZnO}$ and $\mathrm{g}-\mathrm{C}_{3} \mathrm{~N}_{4}$ precursor materials were transferred to the alumina crucible and closely packed using aluminum foil. To make $\mathrm{ZnO} / \mathrm{g}-\mathrm{C}_{3} \mathrm{~N}_{4}$ nanocomposite, 1:1 (wt \%) of each precursor material were taken. Thereafter, the obtained powder was heated up in a muffle furnace at $550{ }^{\circ} \mathrm{C}$ for $5-6 \mathrm{~h}$ at a $3{ }^{\circ} \mathrm{C} / \mathrm{min}$ ramp rate. As a result of the calcination, brown to dark brown powder was obtained. The $\mathrm{ZnO}$ nanorods on $\mathrm{g}^{-} \mathrm{C}_{3} \mathrm{~N}_{4}$ sheets were formed after the completion of the process, which was established by various morphological and microstructural characterizations. The schematic representation of the synthesis process is shown in Figure 1.

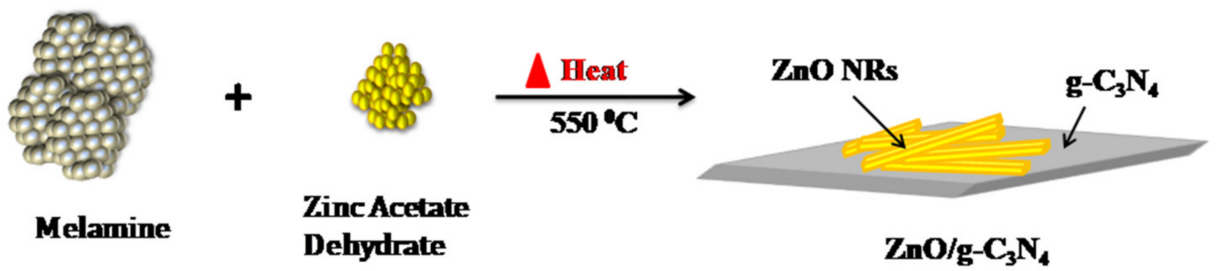

Figure 1. Schematic of $\mathrm{ZnO} / \mathrm{g}-\mathrm{C}_{3} \mathrm{~N}_{4}$ synthesis process.

\section{Material Characterizations}

\subsection{X-ray Diffraction}

The XRD spectrum for $\mathrm{ZnO} / \mathrm{g}-\mathrm{C}_{3} \mathrm{~N}_{4}$ was performed by Rigaku Smart Lab X-ray diffractometer with $\mathrm{Cu} \mathrm{K} \alpha$ radiation $(\lambda=1.5405 \AA)$ and shown in Figure 2. g- $\mathrm{C}_{3} \mathrm{~N}_{4}$ gives two peaks at 12.9 and 27.5 that correspond to 100 and 002 lattices [6,7]. The peak at 27.5 corresponds to interplanar stacking peaks of aromatic rings, and that at 12.9 corresponds to interlayer structure $[6,7]$. The interplanar spacing of the two peaks was obtained as $0.685 \mathrm{~nm}$ and $0.323 \mathrm{~nm}$, respectively. The $\mathrm{ZnO}$ peaks are recorded at 31.8, 34.5, 36.3, 47.6, $56.7,62.9$, and 69.2, which correspond to 100, 002, 101, 102, 110, 103, 112 lattices, respectively (JCPDS 36-1451). No other peaks were recorded, which confirmed the very high purity of the material.

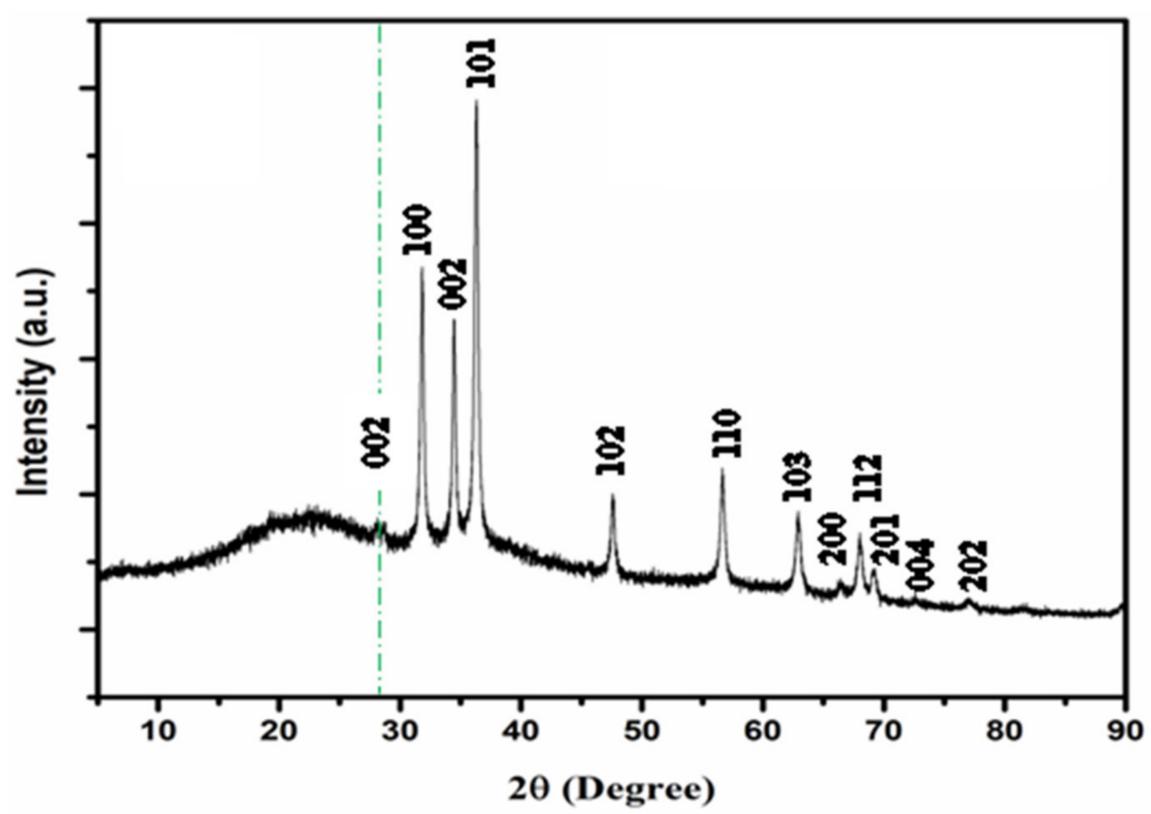

Figure 2. XRD spectra of $\mathrm{ZnO} / \mathrm{g}-\mathrm{C}_{3} \mathrm{~N}_{4}$.

\subsection{FESEM and TEM}

SEM and TEM analyses were performed to investigate the surface morphology and microstructure of the prepared sample. JSM-7600F (FEG) and Philips CM 200 were used for 
SEM and TEM analysis. SEM image reveals the irregular sheets of $g-\mathrm{C}_{3} \mathrm{~N}_{4}$ with variation in size, as shown in Figure 3a. The $\mathrm{ZnO} / \mathrm{g}-\mathrm{C}_{3} \mathrm{~N}_{4}$ show the excellent formation of $\mathrm{ZnO}$ nanorods on the $\mathrm{g}-\mathrm{C}_{3} \mathrm{~N}_{4}$ sheets. The size of the rods is about $400-500 \mathrm{~nm}$. TEM images of the GCN and $\mathrm{ZnO} / \mathrm{g}-\mathrm{C}_{3} \mathrm{~N}_{4}$ are shown in Figure $3 \mathrm{~b}$. The $\mathrm{g}-\mathrm{C}_{3} \mathrm{~N}_{4}$ has $2 \mathrm{D}$ sheets with irregularity in shape and size, as also depicted in SEM. The $\mathrm{ZnO} / \mathrm{g}-\mathrm{C}_{3} \mathrm{~N}_{4} \mathrm{TEM}$ analysis shows the formation of nanorods. $\mathrm{ZnO}$ nanorods are anchored to the $\mathrm{g}-\mathrm{C}_{3} \mathrm{~N}_{4}$ sheet. This confirms the presence of $\mathrm{ZnO}$ in the composites.
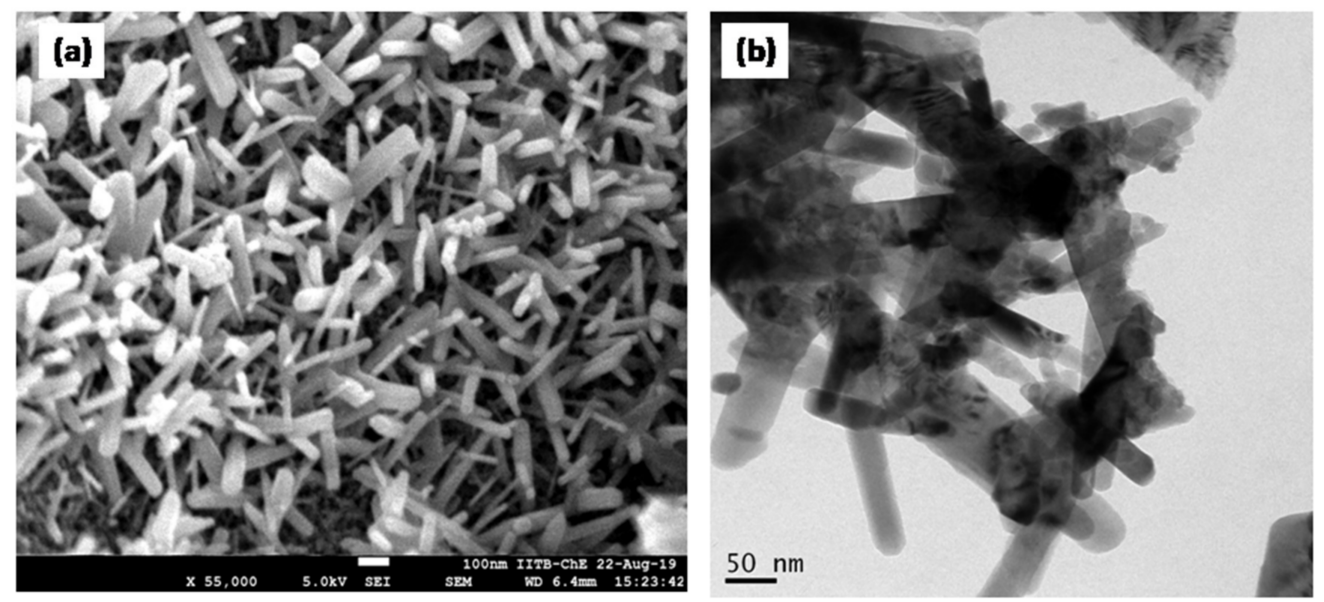

Figure 3. (a) FESEM of $\mathrm{ZnO} / \mathrm{g}-\mathrm{C}_{3} \mathrm{~N}_{4}$; (b) $\mathrm{TEM}$ image of $\mathrm{ZnO} / \mathrm{g}-\mathrm{C}_{3} \mathrm{~N}_{4}$.

\subsection{Energy Dispersive X-ray (EDX) Analysis}

EDX analysis for the synthesized $\mathrm{ZnO} / \mathrm{g}-\mathrm{C}_{3} \mathrm{~N}_{4}$ composite was conducted to confirm the presence of elements. As shown in Figure 4, EDX was performed in the selected area of the $\mathrm{ZnO} / \mathrm{g}-\mathrm{C}_{3} \mathrm{~N}_{4}$ composite. The peaks for $\mathrm{C}, \mathrm{N}, \mathrm{O}$, and $\mathrm{Zn}$ can easily be seen in the EDX spectrum. Apart from these elements, some other element peaks were also observed (which are attributed thin coating required for improving the conductivity and imaging). The elemental area mapping for the selected area and the presence of all the expected elements are clearly evident. Therefore, it is confirmed that the $\mathrm{ZnO} / \mathrm{g}-\mathrm{C}_{3} \mathrm{~N}_{4}$ nanocomposite has all the expected elements present. As there are no other peaks (except for those corresponding to coating), the synthesized $\mathrm{ZnO} / \mathrm{g}-\mathrm{C}_{3} \mathrm{~N}_{4}$ composite was concluded to be of high purity.

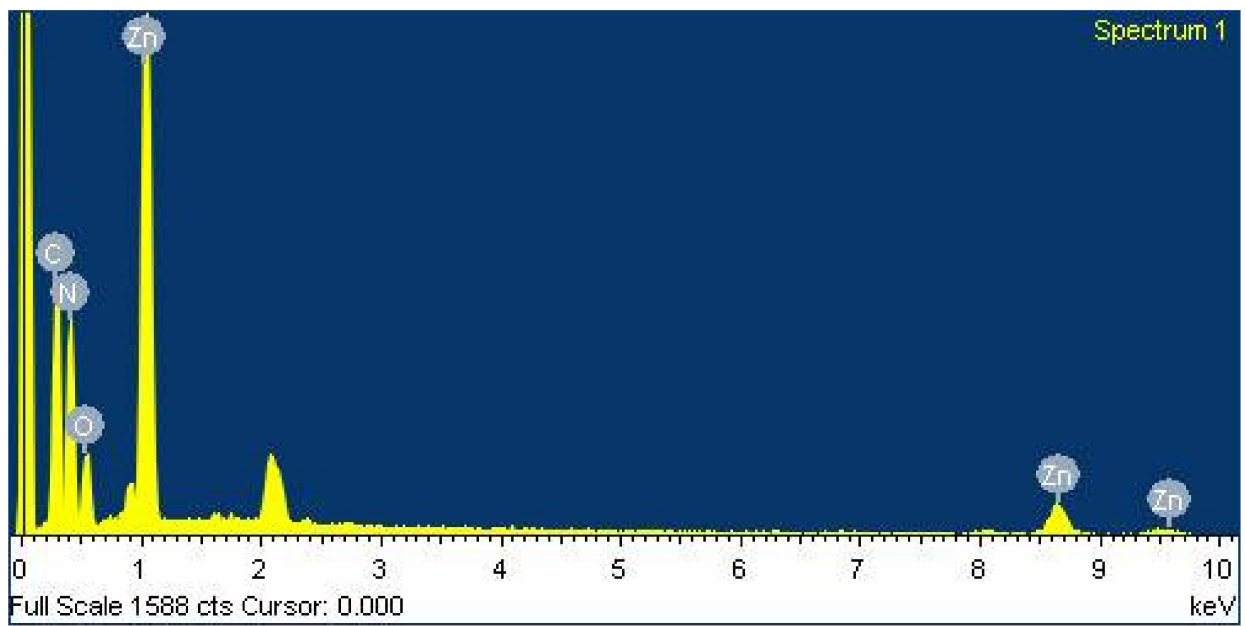

Figure 4. EDX analysis of $\mathrm{ZnO} / \mathrm{g}-\mathrm{C}_{3} \mathrm{~N}_{4}$. Elemental area mapping of $\mathrm{Zn}, \mathrm{O}, \mathrm{N}, \mathrm{C}$.

\section{Gas Sensing Measurement}

Gas sensing measurement has been performed on a fabricated sensor, as shown in Figure 5. Carbon interdigitated electrodes were fabricated on top of pre-cleaned glass 
substrates. Sensing material was deposited by using drop-casting. The home-based sensing chamber was made, which consisted of inlet, outlet, and connection ports for digital multimeter. Pre-calibrated canisters with a flowmeter were used for a controlled and accurate concentration of the analyte gas. Figure 6 shows the change in resistance with respect to various concentrations of gas. The response and recovery time of the sensor were measured for $4 \%$ and $10 \%$ hydrogen gas. The response time for the $4 \%$ hydrogen concentration was observed to be $65 \mathrm{~s}$, and it was $90 \mathrm{~s}$ for $10 \%$ hydrogen concentration, respectively. The temperature was kept at room temperature.

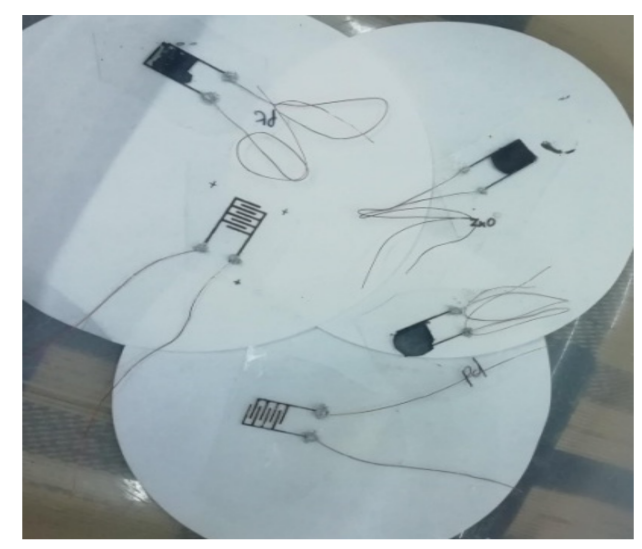

Figure 5. Fabricated $\mathrm{ZnO} / \mathrm{g}-\mathrm{C}_{3} \mathrm{~N}_{4}$ sensor.

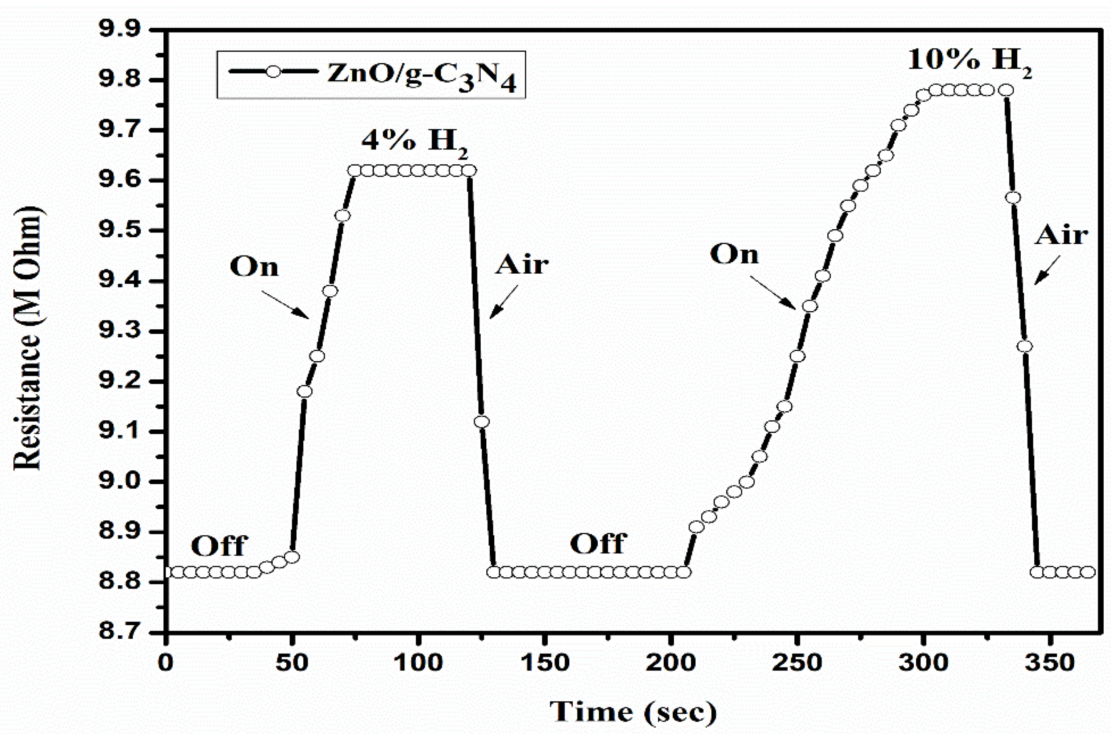

Figure 6. Real-time electrical resistance response of $\mathrm{ZnO} / \mathrm{g}-\mathrm{C}_{3} \mathrm{~N}_{4}$ at $4 \%$ and $10 \% \mathrm{H}_{2}$ concentration at room temperature.

The sensitivity of the $\mathrm{ZnO} / \mathrm{g}-\mathrm{C}_{3} \mathrm{~N}_{4}$ sensor for $4 \%$ and $10 \%$ were evaluated to be $12 \%$ and $15 \%$, respectively. The formula used to calculate the $\%$ sensitivity is given as. Sensitivity of the sensor,

$$
\text { Sensitivity }(\%)=\frac{R_{\text {Air }}-R_{\text {Analyte }}}{R_{\text {Analyte }}} \times 100
$$

where:

$R_{\text {Air }}=$ Resistance in the absence of hydrogen gas (100\% air);

$R_{\text {Analyte }}=$ Resistance in the presence of hydrogen gas.

The sensing mechanism of the sensor is based on the reversible chemisorption process. When the sensor is in off condition, the oxygen atom gets adsorbed on the surface of the 
sensor by taking electrons from the material. Hence, the overall resistance of the senor increases. Conversely, when we introduce analyte gas $\left(\mathrm{H}_{2}\right.$ gas), the hydrogen atom converts into $\mathrm{H}^{+}$and $\mathrm{H}^{-}$molecules. These molecules then react with adsorbed oxygen, make $\mathrm{H}_{2} \mathrm{O}$, and release electron to the interstitial site. As a result, the resistance of the sensor reduces.

\section{Conclusions}

The $\mathrm{ZnO} / \mathrm{g}-\mathrm{C}_{3} \mathrm{~N}_{4}$ nanocomposite was synthesized, followed by various characterizations to explore its properties. XRD showed the presence of all phases and purity of the material. The nanorods were more than $500 \mathrm{~nm}$ in length. $\mathrm{ZnO}$ nanorods were successfully impregnated on top of the graphitic carbon nitride matrix. The hydrogen gas sensing was studied, and promising data was recorded.

Author Contributions: A.I. and U.B.M.: methodology, analysis, synthesis, testing and validation. S.P.D., R.R.K.S. and A.S.: Visualization, supervision, project management and proofreading and language correction. All authors have read and agreed to the published version of the manuscript.

Funding: This research received no external funding.

Institutional Review Board Statement: Not applicable.

Informed Consent Statement: Not applicable.

Data Availability Statement: No external data availability.

Conflicts of Interest: The authors declare no conflict of interest.

\section{References}

1. Luna-Moreno, D.; Monzón-Hernández, D.; Villatoro, J.; Badenes, G. Optical fiber hydrogen sensor based on core diameter mismatch and annealed Pd-Au thin films. Sens. Actuators B Chem. 2007, 125, 66-71. [CrossRef]

2. Wang, A.; Wang, C.; Fu, L.; Wong-Ng, W.; Lan, Y. Recent Advances of Graphitic Carbon Nitride-Based Structures and Applications in Catalyst, Sensing, Imaging, and LEDs. Nano-Micro Lett. 2017, 9, 47. [CrossRef] [PubMed]

3. Wang, X.; Maeda, K.; Thomas, A.; Takanabe, K.; Xin, G.; Carlsson, J.M.; Domen, K.; Antonietti, M. A metal-free polymeric photocatalyst for hydrogen production from water under visible light. Nat. Mater. 2009, 8, 76-80. [CrossRef] [PubMed]

4. Dong, Y.; Wang, Q.; Wu, H.; Chen, Y.; Lu, C.-H.; Chi, Y.; Yang, H.-H. Graphitic Carbon Nitride Materials: Sensing, Imaging and Therapy. Small 2016, 12, 5376-5393. [CrossRef]

5. Liu, J.; Wang, H.; Antonietti, M. Graphitic carbon nitride "reloaded": Emerging applications beyond (photo)catalysis. Chem. Soc. Rev. 2016, 45, 2308-2326. [CrossRef] [PubMed]

6. Ibrahim, A.; Memon, U.; Duttagupta, S.; Mahesh, I.; Raman, R.S.; Sarkar, A.; Pendharkar, G.; Tatiparti, S.S. Nano-structured palladium impregnate graphitic carbon nitride composite for efficient hydrogen gas sensing. Int. J. Hydrog. Energy 2020, 45, 10623-10636. [CrossRef]

7. Ibrahim, A.; Memon, U.; Duttagupta, S.; Raman, R.S.; Sarkar, A.; Pendharkar, G.; Tatiparti, S. Hydrogen gas sensing of nanoconfined Pt/g-C3N4 composite at room temperature. Int. J. Hydrog. Energy 2021, 46, 23962-23973. [CrossRef] 